\title{
Corporate Governance Characteristics as a Stimulus to Tax
}

\section{Management}

\author{
Antônio Paulo Machado Gomes
}

Ibmec, Departamento de Ciências Contábeis, Belo Horizonte, MG, Brazil

Received on 06.27.2014-Desk Acceptance on 10.28.2014-3 $3^{\text {rd }}$ version accepted on 09.25.2015

\begin{abstract}
This article aimed to investigate whether corporate governance uses tax management to increase companies' performance. The objective was checking whether corporate governance characteristics, such as remuneration paid to the executive board, segregation between Chairman and CEO, and the independence and composition of the Board of Directors, influence tax management in Brazilian companies. At the same time, it aimed to identify whether the preceding tax management is reflected on the subsequent tax management. To do this, a sample of 355 Brazilian companies listed on the BM\&FBOVESPA between 2008 and 2014 was used, in order to find out whether their corporate governance characteristics influenced tax management, something identified by calculating ETR, CashETR, and BTD. As a result, it was found (i) that the remuneration paid to executives may be regarded as a characteristic influencing tax management in Brazilian firms, and (ii) that the preceding tax management influences the future tax management. In addition, it was found that Brazilian companies do not rule out tax management benefits, since the average effective rate in the sample under analysis was $25 \%$, and it is statistically lower than the nominal rate of taxes on earnings in Brazil, which is $34 \%$.
\end{abstract}

Keywords: tax management, corporate governance, ETR, CashETR, BTD. 


\section{INTRODUCTION}

As noticed by Desai and Dharmapala (2007), concerning the study by Adolphe Berle and Gardiner Means on the agency problem (The Modern Corporation and Private Property, 1932), the latter arises when shareholders name managers who can pursue interests of their own at the expense of shareholders' interests. According to Desai and Dharmapala, the authors were inspired by the role of taxes in the diffusion of property in the U.S. economy, and this was due to high tax rates on estate and the need for funding after the First World War, which resulted in property segregation among the U.S. companies. The agency problem has emerged along with this separation between owners and managers, according to Shleifer and Vishny (1997) and La Porta and Vishny (2000), and it is solved by adopting good Corporate Governance practices.

According to Silveira (2004), studies involving the theme corporate governance have as their main concern demonstrating the increased companies' performance by adopting the principles of corporate governance. On the other hand, according to Minnick and Noga (2010), these studies are not concerned in checking how increased performance is obtained. Therefore, in order to verify which are the tools used by corporate governance to boost corporate performance, this research examines whether companies seek to increase their performance by reducing expenses on taxes on earnings (Brazilian income tax on legal entities - IRPJ and Brazilian social contribution on earnings - CSLL) and whether this is motivated by corporate governance practices adopted by companies.

It is believed that the increased performance of a company can be reached through tax management, understood as a legal way of reducing expenses on taxes, when taxpayers identify opportunities in laws to decrease companies' tax burden (Goncharov \& Zimmermann, 2005; Tang, 2005; Desai \& Dharmapala, 2006; Formigoni, Antunes, \& Paulo, 2009; Minnick \& Noga, 2010; Tang \& Firth, 2010).

Many studies (Desai \& Dharmapala, 2006; Dyreng, Hanlon, \& Maydew, 2008; Robinson, Sikes, \& Weaver, 2010; Armstrong, Blouin, \& Larcker, 2011) report that tax management may be measured through three proxies: Effective Tax Rate (ETR), Cash Effective Tax Rate (CashETR), and Book-Tax Differences (BTD). It is understood as ETR the result of dividing expenses on taxes on earnings by company's earnings before taxes on earnings; so, ETR is the effective tax rate on company's profit. In turn, CashETR is the effective tax rate taking only paid taxes into account, without deferred taxes and analyzing in the long term. And, finally, BTD is the difference between book earnings and taxable earnings, considering that, if the latter is smaller than the former, there is evidence of tax management.

Given this preliminary context, the link between tax management and corporate governance is discussed for two reasons. First, tax management can be complex and obscure, i.e. in order to obtain an effective tax management the company may be encouraged to adopt complex corpo- rate structures or invest in tax havens that do not require accounting information. Thus, it gives room for managerial opportunism, i.e. within complex and obscure structures managers have opportunities to pursue interests of their own to the detriment of shareholders' interests. An example of this practice was reported by Desai and Dharmapala (2007) regarding the conclusions by the Joint Committee on Taxation (JCT) in the ENRON case. According to this Committee, the fraud at ENRON had as its initial goal tax savings. However, such planning was used to mask losses and thus cheat thousands of investors around the world. The Enron case demonstrates how tax management can provide ideal environments for managerial opportunism. Second, tax management involves significant uncertainties, since it must be executed before the taxable event so that it does not characterize tax avoidance, i.e. tax crime. Thus, the benefits of tax management may fail to occur.

Therefore, knowing how corporate governance will work to (i) mitigate risks for a complex and obscure tax management and (ii) contribute so that the benefits of tax management take place provides some understanding to shape corporate governance practices in order to lead the company to achieve the shareholders' main goal, i.e. increased firm value. Also, Brazil has experienced an actual growth of the stock market, where more and more investors employ their savings in publicly traded corporations. Accordingly, the agency problem risk increases and it must be discussed. Another aspect that deserves attention is tax management in companies, as the Brazilian tax legislation complexity, coupled with the increased expenses on taxes, may encourage companies to manage their taxes, giving room to managerial opportunism.

According to the manuals on good corporate governance practices by the Brazilian Securities and Exchange Commission (CVM) (Comissão de Valores Mobiliários, 2002) and the Brazilian Institute of Corporate Governance (IBGC) (Instituto Brasileiro de Governança Corporativa, 2011), a company can boost its performance, as well as bring benefits to the whole society, by adopting internal and external mechanisms to ensure that corporate decisions are made in the best interest of investors, in order to maximize the probability that resource providers have a return on their investment.

To do this, one of the main internal mechanisms that these manuals propose refers to the Board of Directors, which, according to Silveira (2002), plays a key role in companies' corporate governance, therefore it is the main internal mechanism to reduce agency costs between shareholders and managers, as well as between controlling and minority shareholders.

According to Fama and Jensen (1983), the decision-making process of senior management involves four stages, two of which should be the sole responsibility of the Board: ratification of relevant decisions and monitoring of senior management. In this way, according to the manu- 
als on corporate governance by the CVM (2002) and the IBGC (2011), the Board of Directors should be independent and there must be segregation between the president of the Board of Directors (Chairman) and the chief executive officer (CEO), in order to enable the Board to play its role of effectively monitoring the executive board, contributing to maximize companies' performance.

The aforementioned manuals propose that the Board of Directors consists of few members, technically qualified, ranging from five to nine participants. This suggestion is derived from the organizational behavior theory, which reports a productivity decline as the working groups increase. In this way, according to Jensen (2001), Boards with a large number of members are less likely to work effectively, becoming more easily controlled by the executive director. In addition, several studies (Yermack, 1996; Brown \& Maloney, 1999; Eisenberg, Sundgren \& Wells, 1998; Füerst \& Kang, 2000) have demonstrated that smaller Boards are more efficient and they provide companies with better returns.

In addition the Board of Directors, a way to mitigate the agency problem is through incentive contracts, which aim to establish rewards and punishments to managers and thus align managers' interests to shareholders' interests. In this way, a partial solution to the issue of executives' residual control right is providing managers with an ex-ante long-term incentive, which align executives' interests to investors' interests (Jensen \& Meckling, 2008).

Fama (1980) shows that incentive contracts can take a variety of forms, including property distribution, options to purchase stocks, or threat of dismissal if performance is bad. On the other hand, according to Shleifer and Vishny (1997), the main issue of incentive contracts is that they create a huge potential for managers' extra earnings, e.g. earnings from profits already known or goals already met.

Anyway, several studies (Desai \& Dharmapala, 2006; Frank, Lynch \& Rego, 2009; Rego \& Wilson, 2010; Dyreng, Hanlon \& Maydew, 2010; Armstrong et al., 2011) have shown a strong link between the executive board remuneration and tax management, showing a negative relationship between increased executive board remuneration and the effective tax rates on companies' earnings.

Thus, it is believed that the composition of the Board of Directors, its members' independence, segregation between the president (chairman) and the chief executive officer (CEO), and the proper design of executive board remuneration contracts are corporate governance characteristics that can (i) influence the increased corporate performance, by reducing expenses on taxes, (ii) avoid agency problems in situations where tax management enables managerial opportunism, and (iii) avoid the uncertainty of benefits from tax management, minimizing the allocation of resources in dubious tax management.

Given the above, this research problem has been prepared: Corporate governance characteristics, such as executive board remuneration, segregation between Chairman and CEO, the independence and composition of the Board of Directors, as well as tax management in preceding years, influence tax management in Brazilian companies?

\section{LITERATURE REVIEW AND DEVELOPMENT OF HYPOTHESES}

\subsection{Aspects Related to Tax Management}

According to the literature reviewed by Graham (2003), taxes are one of the many factors influencing decision-making in companies, especially with regard to investment and funding policies. Given this fact, Hanlon and Slemrod (2007) report that shareholders are interested to reduce the burden of taxes in order to increase company value.

Tax management, tax administration, tax planning, and tax avoidance are defined as a legal way of reducing expenses on taxes, when taxpayers identify opportunities in the laws to decrease companies' tax burden (Armstrong et al., 2011; Desai \& Dharmapala, 2006; Formigoni et al., 2009; Minnick \& Noga, 2010; Tang \& Firth, 2010; Goncharov \& Zimmermann, 2005).

Therefore, tax management seeks, through legal ways and among the opportunities observed in tax legislation, to reduce the current value of companies' taxes in order to increase their performance and, as a consequence, their market value (Machado, 2011). In this vein, Desai and Dharmapala (2006) report that tax management is a legal transfer of State resources to companies with a view to increase their performance, by reducing expenses on taxes. As a result, many researchers have shown that tax mana- gement is a valuable activity for shareholders (Bankman, 1999; Graham \& Tucker, 2006; Desai \& Dharmapala, 2007; Frank et al., 2009; Wilson, 2009).

According to Scholes and Wolfson (1992), there is a need to consider all aspects involved in business and not only taxes to make tax management effective. In this way, the conceptual structure developed by the authors revolves around three central themes (known as all parties, all taxes, and all costs):

a) An effective tax planning requires the planner to take into account the tax implications of a transaction proposed for all parties involved in the transaction (all parties).

b) An effective tax planning requires the planner, when making investments and financial decisions, to take into account not only explicit taxes, value paid directly to the authorities, but also implicit taxes, value paid indirectly in the form of lower return rates before taxes on encouraged investments (all taxes).

c) An effective tax planning requires the planner to recognize that taxes represent only one among many business costs, and all of them must be considered in the planning process; to be implemented, some proposals require costly restructuring procedures (all costs). 
Therefore, it is clear that the central theme in the structure developed by Scholes and Wolfson (1992) is that the effective tax management must take into account (i) tax implications for all parties involved in the transaction, (ii) all taxes, either explicit or implicit, and (iii) all costs involved in the issue.

According to these authors, although taxes represent a significant burden on companies' cost structure and, therefore, require due attention, decision-making to reduce companies' tax burden may not be based only on the legal-fiscal perspective. Checking all variables involved in tax management is important so that the intended goal and gain are achieved, regardless of their nature, fiscal or non-fiscal.

Finally, the authors highlight that increasing companies' performance is more important than reducing companies' tax burden, because what really matters is maximizing company value (Scholes \& Wolfson, 1992). Therefore, tax management must have as its primary premise increasing company value in the long term.

Studies related to tax management usually seek to connect fiscal management to certain company's attributes, such as profitability, foreign operations level, intangible assets, expenses on research and development (R\&D), leverage, and aggressive financial reporting. Some examples of these studies are Gupta and Newberry (1997), Rego (2003), Graham and Tucker (2006), Frank et al. (2009), and Wilson (2009).

In this paper, the aim is identifying whether corporate governance characteristics adopted by companies, such as independence of the Board of Directors, the number of members in this Board, segregation between Chairman and $\mathrm{CEO}$, and variable remuneration influence tax management. In this line of research, evidence is mixed, according to results obtained by Phillips (2003), Hanlon (2005), Desai and Dharmapala (2006), and Armstrong et al. (2011).

Several studies (Desai \& Dharmapala, 2006; Dyreng et al., 2008; Robinson et al., 2010; Armstrong et al., 2011) report that tax management may be measured through three proxies: Effective Tax Rate (ETR) Cash Effective Tax Rate (CashETR), and Book-Tax Differences (BTD). It is understood as ETR the result of dividing expenses on taxes on earnings by company's earnings before taxes on earnings, thus ETR is the effective tax rate on company's profit. In turn, CashETR is the effective tax rate taking only paid taxes into account, without deferred taxes and analyzing in the long term. To do this, it is highlighted that this variable was obtained by adding the expenses registered in companies' results over the past 10 years and dividing this value by earnings before taxes on earnings, within the same 10year period. Expenses registered in the result were taken into account, because they are the counterparts of tax liabilities registered in the short term and settled by March 31 of the subsequent year, according to the Brazilian Income Tax Regulations (Decree 3,000/1999). So, these are the values actually paid by companies. And, finally, BTD is the difference between book earnings and taxable earnings, if the latter is smaller than the former, there is evidence of tax management.

Through these proxies, studies sought to determine whether there was a relationship between variable remuneration and tax management, and in many of these papers there was a significant negative relationship between remuneration and the proxies to identify tax management - ETR, CashETR, and BTD. This leads to the conclusion that remuneration influences directly tax management, demonstrating that proper design of variable remuneration contracts is one of the great corporate governance tools to mitigate the agency problem and incentives to increase companies' performance, by reducing income taxes.

In this way, Phillips (2003) reports that managers seek tax management to achieve their goals and thus increase their remuneration. Providing the same conclusion, Desai and Dharmapala (2006) notice there is a significant negative relationship between increases in the executive board variable remuneration and the proxy BTD to identify tax management. In addition, the authors report that the negative effect observed also stems from corporate governance characteristics adopted by the company. According to the authors, companies having weak corporate governance are more likely to tax management when the executive board variable remuneration increases.

In the same vein, Rego and Wilson (2010) examined variable remuneration as one determinant of tax management. Based on prior research, they concluded that variable remuneration led administrators to take more risks in investment and funding decisions, provided that risk increased their variable remuneration. The authors identified a relationship between variable remuneration and the tax management proxies BTD and CashETR. However, they did not identify the same association with corporate governance characteristics, such as independence of the Board of Directors and segregation between Chairman and CEO.

Dyreng et al. (2010) analyzed 908 business executives between the years 1992 and 2006, in order to verify whether these managers promoted an incremental effect on tax management in their companies, since such management could not be explained by the company characteristics. They noticed that executives play a significant role in determining companies' tax avoidance level. The authors identified a significant impact between these managers and the two tax management proxies used in the study - ETR and CashETR.

In the paper by Minnick and Noga (2010), addressing the role of corporate governance in tax management, the authors identified that variable remuneration of executive directors and the CEO have a strongly negative relationship with the tax management proxies ETR and CashETR. Every dollar added to the executives' wealth accounts for 1.94\% less in ETR and $4.13 \%$ less in CashETR. Therefore, the authors conclude that remuneration is the best corporate governance tool to encourage tax management in companies. Besides, they also noticed that small Boards of Directors are more prone to tax management held abroad, while companies with large Boards and independent members focus on domestic tax management, i.e. within their 
own country.

Armstrong et al. (2011) analyzed whether executives' variable remuneration directly related to tax management led them to focus on tax management. As a result, the authors identified a strongly negative relationship between the remuneration of these executives and the ETR. However, they did not find the same relationship with regard to the CashETR.

\subsection{Corporate Governance, Agency Problem, and Player Remuneration}

Corporate governance began in the USA as a way to fight the expropriation of shareholders by executive managers, i.e. it emerged as a response to several records of misuse of shareholder's wealth by managers. Indeed, the authors classify corporate governance as the set of mechanisms through which outsider investors (shareholders or creditors) protect themselves against expropriation by insider investors (executives or controlling shareholders). Therefore, corporate governance aims to ensure that resources allocated by investors will not be spent by executive managers in activities that do not bring them the best return (Shleifer \& Vishny, 1997; La Porta \& Vishny, 2000).

On the core of the discussion of corporate governance lies the agency problem that, as claimed by Jensen and Meckling (2008), is characterized by the conflict of interests between investors (the principal) and executive managers (the players), when the latter work in their own interest at the expense of shareholders' aspirations. In this vein, given the information asymmetry, the player, aware that his actions are not fully known by the shareholder, can use company resources with less zeal than the shareholder. Therefore, the essence of the agency problem is the conflict of interests made possible by separation of ownership and control and it refers to investors' difficulties to ensure that their funds are not expropriated or lost in unattractive projects.

To fight this opportunism, there emerge costs to align managers' interests to shareholders' interests. Such agency costs are classified by Jensen and Meckling (2008) into four types: the costs of generating incentives or outline behavior (bonding), monitoring costs (monitoring), signaling costs (signaling), and residual losses (residual loss). The first type derives from efforts to restrict player's choices, by encouraging him to behave according to a standard and warning him to expect punishment when deviating from such a standard. The second type is related to monitoring efforts by the principal to break with the information asymmetry, in order to provide the player with a sense of control. Considering the cost-benefit ratio of control and return, there is a point where it is not worth expending more effort to control players; so, these losses are acceptable, i.e. residual losses (Cardoso, Mário \& Aquino, 2007).

Thus, the concern of Corporate Governance is fighting the agency problem, creating an effective set of mechanisms, both incentives and monitoring, in order to ensure that executives' behavior is always aligned to shareholders' interests. Thus, good governance provides owners (shareholders or unit holders) with strategic management of their company and monitoring of executive administration.

To ensure this goal, executives and shareholders sign a contract that specifies what managers should do with company resources. Ideally, managers should sign a full contract specifying exactly what to do every moment and how excess cash flow should be allocated, in every possible contingency. The issue is that players have limited knowledge, so many contingencies are difficult to describe and predict, making it clear that full contracts are technically unfeasible. Due to difficulties in their development, investors have to delegate residual control rights to managers, i.e. they have the right to make decisions under circumstances not provided for in the contracts. This situation, in line with information asymmetry, gives rise to an incorrect executives' behavior, considering their personal interest.

However, according to Jensen and Meckling (1976, p. 310), "[...] a partial solution to the issue of executives' residual control rights is giving them a long-term ex-ante incentive to align their interests to investors' interests." Fama (1980) demonstrates that incentive contracts can take a variety of forms, including property distribution, options to purchase stocks, or threat of dismissal if performance is bad.

In this line, there is extensive literature linking senior executives' remuneration to company performance (Coughlan \& Schmidt, 1985; Jensen \& Murphy, 1990), and many of these papers have related the composition and influence of the Board to executives' remuneration (Lambert, Larcker \& Verrecchia, 1991; Boyd, 1994; Hallock, 1997). There are also several studies that oppose remuneration to fiscal management, by checking whether remuneration encourages tax management (Desai \& Dharmapala, 2006; Dyreng et al., 2008; Robinson et al., 2010; Armstrong et al., 2011).

In this regard, the studies sought to confirm whether there is a relationship between variable remuneration and tax management, and in many of them there was a significant negative relationship between remuneration and proxies identifying tax management, such as ETR, CashETR, and BTD (Armstrong et al., 2011; Desai \& Dharmapala, 2006; Dyreng et al., 2010; Minnick \& Noga, 2010; Phillips, 2003; Rego \& Wilson, 2010).

In addition to remuneration, the studies on corporate governance establish that the Board of Directors is a major internal mechanism to solve the agency problem, because it acts as a link in the relations between shareholders and managers and between controlling shareholders and minority shareholders (Jensen, 1993).

Jensen (1993) characterizes the Board of Directors as a major internal monitoring mechanism to protect owners' interests. According to Silveira (2002), several market players even associate the term "corporate governance" to the active and independent role of the Board of 
Directors. In fact, when analyzing the history of corporate governance, it is noticed that the Board of Directors, as well as its independence from the beginning, was highlighted as the main internal mechanism to reduce agency costs between shareholders and managers and, as a consequence, to improve company performance.

Johnson, Daily and Ellstrand (1996) cite three functions of the Board of Directors: control, consultancy, and identification of resources. Regarding control, the Board acts as an internal body of the company responsible for monitoring directors, and it represents, within the company, owners' aspirations. In this role, the responsibilities of the Board of Directors include hiring and firing the $\mathrm{CEO}$ and other executives. Moreover, it is up to the Board establishing executives' remuneration and punishment and ensuring that shareholders are not expropriated by senior managers (Monks \& Minow, 1995). As for consultancy, the Board plays an advising role towards directors, recommending and confirming strategies to achieve the organization's goals. And, finally, according to Pfeffer and Salancik (1978), the Board also plays the role of resource finder aiming at company's success.

The widespread idea that the main function of the Board is monitoring company management and that only external professional counselors can be effective monitors has led most governance codes to emphasize the need for a Board of Directors made up of a majority of members external to the company (non-executive, independent), in order to improve decision-making and increase company value (Silveira, 2002).

Following this line of thought, Fama and Jensen (1983) argue that the inclusion of professional external directors increases the Board effectiveness and reduces the likelihood of collusion of senior executives to expropriate shareholders' wealth. However, there is a conflict of views on how the independence of the Board affects companies' monitoring and performance.

The literature on corporate governance also shows that the composition of the Board, regarding the number of independent members, is related to mitigation of agency problems (Hermalin \& Weisbach, 1991; Byrd \& Hickman, 1992; Borokovich, Parrino \& Trapani, 1996; Yermack, 1996; Core, Holthausen \& Larcker, 1999). In fact, this literature has shown that large Boards with few independent counselors had more agency problems. On the other hand, companies with small Boards and a greater number of external members might be safeguarded, because in this case the Board would be rather concerned about shareholders' well-being improved company performance.

Based on this view, several studies tried to relate the independence of the Board of Directors to company performance. According to Silveira (2002), the question to be answered in these surveys was "[...] does a Board made up of a majority of external members (non-executive) increase company performance?" To answer it, researchers examined the correlation between accounting performance measures and the proportion of counselors external to the Board, and some results were conflicting (Rosenstein \& Wyatt, 1990; Weisbach, 1988; Baysinger \& Butler, 1985; Bhagat \& Black, 2000; Hermalin \& Weisbach, 1991; Byrd \& Hickman, 1992; Agrawal \& Knoeber,1996).

Bhagat and Black (2000) found a significant relationship between the composition of the Board and corporate performance, noticing that the Boards of U.S. companies with a majority of independent members behave differently from the Boards without such a majority, and some of the differences seem to contribute to increase company value, while others seem to contribute to its reduction. However, contrary to what is advocated by most corporate governance codes, these authors state there is convincing evidence that the greater independence of the Board, represented by a majority of non-executive company counselors, is correlated to increased company profitability or faster growth.

According to Bhagat and Black (2000), there is no empirical support to claim that companies whose Boards have more independent members show a better performance. On the contrary, the authors state there is evidence that companies whose Board has a majority of independent members are less profitable, since they showed a worse performance when compared to other companies in the study.

However, by contrast, Hermalin and Weisbach (1991) think there is a tendency for companies that have gone through difficulties to include independent members in the Board in order to improve their performance. Thus, the authors state that the correlation between composition of the Board and corporate performance tends to make companies with a higher proportion of members external to the Board to look worse, given the correlation between the proportion of external counselors and poor historical performance.

Anyway, Bhagat and Black (2000) claim that companies with an independent majority may even perform better in some specific tasks, such as replacing the CEO, but they perform worse in other tasks, leading to a non-significant net advantage in general performance. In conclusion, the study suggests it is interesting to include a moderate number of internal and external members in the Board of Directors.

In this vein, Coles, Daniel and Naveen (2008) notice that the Board of Directors may vary according to company characteristics, since, in their study, complex companies have large Boards with more external members, something which contributes to their strategies. On the other hand, simple companies have smaller Boards with few independent members.

Yermack (1996), in turn, found a significant negative correlation between the proportion of independent counselors and Tobin's $Q$, the same finding obtained by Agrawal and Knoeber (1996).

Other studies provide clues of a negative curvilinear relationship between performance and proportion of independent counselors, suggesting that some Boards 
may have too many independent members. One of these studies is Wagner, Stimpert and Fubara (1998), which shows evidence of a curvilinear relationship with a negative coefficient between the composition of the Board and return on assets (ROA). The study suggests that Boards with a balanced proportion between executives and non-executives perform better. The authors emphasize, however, that this correlation disappears when return on equity (ROE) is used as a performance measurement. Barnhart and Rosenstein (1998) also found a curvilinear relationship with a significant negative coefficient between Tobin's $\mathrm{Q}$ and the proportion of independent members in the Board, and they claim that companies with highly independent Boards have lower value, confirming the conclusions by Bhagat and Black (2000).

The studies by MacAvoy, Cantor, Dana and Peck (1983), Baysinger and Butler (1985), and Hermalin and Weisbach (1991) are also noteworthy, which simply did not find any significant relationship between the composition of the Board of Directors and corporate performance measurements.

In Brazil, research on companies' independence and performance were strongly influenced by the U.S. methodology. The most detailed research on this theme was conducted by Mônaco (2000), who analyzed 647 companies registered by the CVM, using data for the year 1996.

By relating the literature highlighted to the question to be answered in this research, independent counselors may provide useful knowledge derived from their experience to the $\mathrm{CEO}$ and the other executives, in order to advise them to concentrate their efforts on fiscal management as a way to increase companies' overall performance. Thus, herein, it is assumed that independent counselors may be more willing to employ resources in fiscal management as a way to ensure a good performance.

In addition to the Board, internal mechanisms such as the remuneration system and the ownership of stocks by executives, and external mechanisms, such as the disclosure of periodic information on the company, the presence of a market for hostile takeovers, and the existence of a competitive job market, are also important to reduce the agency problem (Silveira, Barros \& Famá, 2003).

This research examines corporate governance concerning four aspects, namely: composition and independence of the Board of Directors, size (number of Board members), segregation between Chairman and CEO, and executives' remuneration.

\subsection{Research Hypotheses}

Through the research question six hypotheses were formulated, based on the relationship between corporate governance characteristics and tax management, adopted by companies listed on the BM\&FBOVESPA. The research hypotheses tested were:

$\left(\mathbf{H}_{1}\right)$ The companies listed at the various corporate governance levels on the BM\&FBOVESPA (Level 1, Level 2, and New Market) are those having better fiscal management, as a consequence, they are those having lower ETR and CashETR indexes, as well as positive BTD figures.

$\left(\mathbf{H}_{2}\right)$ The specific corporate governance levels on the BM\&FBOVESPA (Level 1, Level 2, and New Market) have a significant negative relationship with the proxies to identify tax management ETR, CashETR, and BTD.

$\left(\mathrm{H}_{3}\right)$ The number of members in the Board of Directors in the preceding year contributes to tax management in firms, so the number of counselors has a significant relationship with the proxies to identify tax management ETR, CashETR, and BTD.

$\left(\mathbf{H}_{4}\right)$ Independent Boards of Directors are more efficient concerning fiscal management, as they recommend the executive board to invest resources in such activities, so the number of independent counselors in the preceding year has a significant negative relationship with the proxies to identify tax management ETR, CashETR, and BTD.

$\left(\mathbf{H}_{5}\right)$ Companies with segregation between Chairman and CEO are more efficient concerning fiscal management, so this dummy has a significant negative relationship with the proxies to identify tax management ETR, CashETR, and BTD.

$\left(\mathbf{H}_{6}\right)$ Companies that adopt executive board variable remuneration are more efficient concerning fiscal management, so executive board remuneration has a significant negative relationship with the proxies to identify tax management ETR, CashETR, and BTD.

$\left(\mathbf{H}_{7}\right)$ Tax management in the preceding period is reflected on tax management within the subsequent period, so the dependent variables to identify tax management ETR, CashETR, and BTD lagged one year have a significant relationship with the proxies to identify tax management.

\section{METHODOLOGICAL PROCEDURES}

\subsection{Research Type and Method}

As pointed out by Watts and Zimmermann (1986), the accounting theory aims to explain and predict accounting practice. In this sense, this research may be characterized as theoretical and empirical, as it seeks to explain tax management and predicts such management by identifying characteristics that influence it. Thus, the research is divi- ded into two major groups, one having an exploratory and another having an explanatory nature.

The first group, exploratory, seeks to better explain tax management, because, according to Salomon (1973), exploratory research aims to better define the problem, i.e. become familiar with the phenomenon under study. According to Mattar (1999), exploratory research is useful 
when people are aware of the study theme, promoting greater understanding and establishing priorities.

The second group, explanatory, people try to identify which are the corporate governance characteristics adopted by Brazilian companies that influence tax management by increasing their performance. To do this, hypotheses were formulated through existing theories that have been tested by using regression models with panel data.

In addition, research is characterized as quantitative by employing descriptive statistics and statistical analysis. Regarding research strategy, bibliographic and documentary research were used. Concerning the data collection technique, there was a documentary research of financial statements of companies listed on the BM\&FBOVESPA, using the Economatica database to identify, (i) companies' net profit before taxes, (ii) expenses on earnings (current and deferred), and (iii) companies' leverage degree. Besides, there was a detailed examination of the Reference Forms published by companies listed on the BM\&FBOVESPA, according to the CVM Normative Instruction 480/2009. It is noteworthy that these forms have collected information on corporate governance characteristics, such as segrega- tion between Chairman and CEO, the number of independent members in the Board of Directors, total number of members in the Board of Directors, and variable remuneration paid to the executive board.

\subsection{Measurements to Identify Tax Management: ETR, CashETR, and BTD}

According to the literature on calculation of the effective tax rate (ETR), the ETR is commonly used to measure tax management, since it calculates the effective rate of the tax paid by companies (Stickney \& McGee, 1982; Gupta \& Newberry, 1997; Callihan, 1994; Mills, Erickson, \& Maydew, 1998; Petroni \& Shackelford, 1999; Gupta \& Mills, 2002; Yin, 2003; Rego, 2003; Phillips, 2003; Minnick \& Noga, 2010; Armstrong et al., 2011).

According to several researchers (Callihan, 1994; Mills \& Newberry, 2001; Shackelford \& Shevlin, 2000; Tang, 2005; Formigoni et al., 2009; Comprix, Mills \& Schmidt, 2011; Minnick \& Noga, 2010; Armstrong et al., 2011), annual ETR is defined as the percentage obtained by dividing the total expenditure on taxes on earnings by earnings before IRPJ of a given company $i$ in year $t$ :

$$
\operatorname{ETR}_{i, t}=\frac{\text { IncomeTaxes }_{i, t}}{\operatorname{LAIR}_{i, t}}
$$

where 'Income Taxes' is the sum of expenses on IRPJ and CSLL for the current and deferred year, and 'LAIR' is company profit before IRPJ.

Therefore, to identify tax management in companies, the ETR of companies listed on the BM\&FBOVESPA was calculated between 2001 and 2014. It is noteworthy this research regarded as companies practicing tax management those having ETR indexes statistically lower than nominal tax rates on earnings, which amount to $34 \%$ in Brazil.

In order to demonstrate that the effective rates identified by calculating the ETR are lower than normal tax rates on earnings, the signal test was applied to one sample in order to estimate the median value for population and compare it to a target value. Such non-parametric test was applied because the population addressed in this research does not have a normal distribution.

One-sample signal test is a non-parametric alternative to one-sample t-test because it does not require that data come from a normally distributed population, as required by t-test. Besides, a 1-sample signal test has no assumptions on population symmetry.

This research also estimated the Cash Effective Tax Rate
(CashETR) as an additional means to identify tax management in Brazilian companies.

According to Dyreng et al. (2008), the CashETR considers actually paid taxes, since they take into account, along with due tax, extraordinary payments and realized remuneration, thus becoming a proxy with better disposition to measure long-term tax avoidance in companies.

According to these authors, to calculate the CashETR two modifications are made in the calculation of the ETRS. The first and most important is measuring the effective long-term tax rates, i.e. ten years. The second is that, to do so, a company taxes are added over a 10 -year period and then divided by the sum of their total earnings before taxes, over the same ten years. This produces an effective tax rate that better follows up the long-term tax burden of a company.

In addition, to calculate the CashETR only realized tax payments are considered, excluding deferred taxes, due to tax differences, because what is sought is identifying the actual tax burden paid on earnings.

Thus, following Dyreng et al. (2008), the CashETR was calculated this way:

$$
\operatorname{CashETR}_{i t}=\frac{\text { Taxespd }_{i t}}{\operatorname{LAIR}_{i t}}
$$


where 'Taxespd' represent the sum of IRPJ paid and CSLL for the year, and 'LAIR' is earnings before IRPJ.

It is noteworthy that, for identifying taxes paid by companies, only the current expenses on taxes were considered, as they represent the counterparts of tax liabilities registered in the companies and settled, according to the tax legislation, until the last day of March in the subsequent year.

Also, in order to highlight the difference between the proxy CashETR and the nominal tax rate on earnings, a 1-sample signal test was applied.

Besides the calculation of these two proxies (ETR and CashETR), as an additional way to identify tax management, the Book Tax Differences (BTD) was calculated, which, according to the literature, is the difference between book earnings and taxable earnings. Therefore, the BTD refers to the difference between book earnings reported in the financial statements and the taxable earnings reported to the tax authorities through ancillary liabilities.

According to the CPC 32, companies are required to make a reconciliation between book earnings and taxable earnings, demonstrating in a note all factors that detach book earnings from taxable earnings.

Therefore, the companies' BTD was calculated through the notes, dividing expenses on taxes on earnings by 0.34 (percentage related to tax rates on earnings within the period under analysis) and, out of this value, earnings were decreased before taxes on earnings. It is worth noticing that, between 2008 and 2014, the BTD was calculated for financial companies by dividing these companies' expenses on taxes on earnings by 0.40 (percentage related to tax rates on earnings of financial companies, since April 2008).

$$
B T D_{i t}=L A I R_{i t}-\left(\frac{\operatorname{ExpTx}_{i t}}{0.34 \text { or } 0.40}\right)
$$

To demonstrate that taxable earnings were lower than book earnings, 1-sample signal test was also applied, assuming as null hypothesis that taxable earnings were equal to book earnings.

\subsection{Sample Selection and Processing}

The target population of this study consisted of $670 \mathrm{com}$ panies, according to information available on the website of the BM\&FBOVESPA on November 5, 2011. However, tho-

$\begin{array}{lc} & \text { N } \\ \text { Sample } & 355 \\ \text { Population } & 670\end{array}$

Figure 1 shows the sectoral classification of the companies under study, as well as their division between the various segments of corporate governance on the se companies that had no data for any variable under study (LAIR, IRPJ, Deferred Taxes, Assets, Indebtedness) were excluded from this population, i.e. companies which did not allow calculating the proxies under analysis between 2001 and 2014 were excluded. In addition, companies that have adopted internally generated goodwill were excluded, because this is regarded as an abusive tax planning practice. Thus, the study sample consists of 355 companies, whose representativeness based on total assets is $78 \%$.

$\begin{array}{cc}\text { Total Assets } & \text { Percentual } \\ 25,490,814,374 & 78 \% \\ 32,573,002,815 & 100 \%\end{array}$

BM\&FBOVESPA. It is noticed that the sample is very heterogeneous, insofar as it has companies from different sectors and specific segments of corporate governance.

\begin{tabular}{|c|c|c|c|c|c|}
\hline Segment & Level 1 & Level 2 & New Market & Traditional & TOTAL \\
\hline FOOD & & & 1 & 5 & 6 \\
\hline BANKS & 3 & & 1 & 9 & 13 \\
\hline $\begin{array}{l}\text { BEVERAGES AND } \\
\text { SMOKE }\end{array}$ & & & & 2 & 2 \\
\hline TOYS AND LEISURE & & & & 2 & 2 \\
\hline TRADE & 1 & 1 & 2 & 5 & 9 \\
\hline COMMUNICATION & & & 1 & & 1 \\
\hline CONSTRUCTION & 1 & & 5 & 8 & 14 \\
\hline REAL ESTATE CREDIT & & & & 2 & 2 \\
\hline
\end{tabular}




\begin{tabular}{|c|c|c|c|c|c|}
\hline PACKAGING & & & & 1 & 1 \\
\hline ELECTRICITY & 6 & 2 & 3 & 23 & 34 \\
\hline $\begin{array}{l}\text { PHARMACEUTICALS } \\
\text { AND HYGIENE }\end{array}$ & & & & 1 & 1 \\
\hline $\begin{array}{l}\text { HOSPITALITY AND } \\
\text { TOURISM }\end{array}$ & & & & 2 & 2 \\
\hline $\begin{array}{l}\text { FINANCIAL OPERA- } \\
\text { TIONS }\end{array}$ & 1 & & & & 1 \\
\hline MACHINES & 2 & 2 & 3 & 9 & 16 \\
\hline $\begin{array}{l}\text { METALLURGY AND } \\
\text { STEEL-MAKING }\end{array}$ & 6 & & 1 & 17 & 24 \\
\hline MINING & 1 & & & 2 & 3 \\
\hline $\begin{array}{l}\text { PAPER AND CELLU- } \\
\text { LOSE }\end{array}$ & 2 & & 1 & 3 & 6 \\
\hline INVESTMENTS & & & 1 & 3 & 4 \\
\hline OIL AND GAS & & & 1 & 3 & 4 \\
\hline CHEMISTRY & 1 & & & 2 & 3 \\
\hline $\begin{array}{l}\text { SANITATION AND } \\
\text { SERVICES }\end{array}$ & & & 1 & 2 & 3 \\
\hline $\begin{array}{l}\text { INSURANCE COMPA- } \\
\text { NIES AND BROKERS }\end{array}$ & & & 1 & & 1 \\
\hline $\begin{array}{l}\text { TRANSPORT AND LO- } \\
\text { GISTICS SERVICES }\end{array}$ & & 1 & 2 & 6 & 9 \\
\hline $\begin{array}{l}\text { TELECOMMUNICA- } \\
\text { TIONS }\end{array}$ & & 1 & 1 & 10 & 12 \\
\hline $\begin{array}{l}\text { TEXTILE AND CLO- } \\
\text { THING }\end{array}$ & 2 & & 1 & 19 & 22 \\
\hline OTHERS & 8 & 12 & 79 & 61 & 160 \\
\hline TOTAL & 34 & 19 & 105 & 197 & 355 \\
\hline
\end{tabular}

Source: Prepared by the author.

It is noteworthy that the analyses of corporate governance characteristics and tax management proxies were performed only for the years between 2008 and 2014, considering that the information on corporate governance studied herein were made available only with the Reference
Form, established by the CVM Instruction 480/2009.

\subsection{Introduction to the Model and Description of Variables}

The basic models used for the analysis are:

$$
\begin{aligned}
& E T R_{i t}=\beta_{1 \text { it }}+\beta_{2 \text { it }-1} E T R_{-1}+\beta_{3 \text { it }+1} \log (R E M)+\beta_{4 i t-1} C \text { OMP }{ }^{2}+\beta_{5} \text { it }-1 \text { INDEP } 2 \\
& +\beta_{6 \text { it }-1} S E G R+\beta_{7 \text { it }} G C+\beta_{8 \text { it }} A T+\beta_{9 i t} A l a v+\varepsilon_{\text {it }} \\
& \operatorname{CashETR}_{\mathrm{it}}=\beta_{1 \mathrm{it}}+\beta_{2 \mathrm{it}-1} \operatorname{CashETR}_{-1}+\beta_{3 \mathrm{it}+1} \log (R E M)+\beta_{4 \mathrm{it}-1} \operatorname{COMP}^{2}+\beta_{5 \mathrm{it}-1} \text { INDEP } 2 \\
& +\beta_{6 \text { it }-1} S E G R+\beta_{7 \text { it }} G C+\beta_{8 \text { it }} A T+\beta_{9 \text { it }} \text { Alav }+\varepsilon_{\mathrm{it}} \\
& B T D_{\mathrm{it}}=\beta_{1 \mathrm{it}}+\beta_{2 \mathrm{it} 1-1} B T D_{-1}+\beta_{3 \mathrm{it}+1} R E M+\beta_{4 \mathrm{it}-1} C O M P^{2}+\beta_{5 \mathrm{it}-1} I N D E P^{2}+\beta_{6 \mathrm{it}-1} S E G R \\
& +\beta_{7 \text { it }} G C+\beta_{8 \mathrm{it}} A T+\beta_{9 \mathrm{it}} A l a v+\varepsilon_{\mathrm{it}}
\end{aligned}
$$


Where:

ETR $=$ Effective Tax Rate, which is a dependent variable in the model;

CashETR = Cash Effective Tax Rate, which is a dependent variable in the model. It is worth noticing that this variable was obtained by summing expenses registered in the companies' outcomes within the last 10 years. Expenses registered in the outcomes were considered because they are the counterparts of tax liabilities registered in the short term, which were settled by March 31 of the subsequent year, according to the Brazilian Income Tax Regulations (Decree 3,000/1999);

BTD = Difference between book earnings and taxable earnings, which is a dependent variable in the model;

$\beta$ 's = Angular coefficients estimated for each dependent variable;

$\mathrm{ETR}_{-1}=$ Dependent variable lagged one year;

CASH-1 = Dependent variable lagged one year;

$\mathrm{BTD}_{-1}=$ Dependent variable lagged one year;

$\log (\mathrm{REM})=$ Remuneration value paid to the executive board in the year subsequent to the calculation of dependent variables in the model. The natural logarithm of remuneration value paid was adopted for calculating the ETR and CashETR;
REM = Remuneration value paid to the executive board in the year subsequent to the calculation of dependent variables in the model. The remuneration value paid was adopted for calculating the BTD;

$(\mathrm{COMP})^{2}=$ Number of members in the company Board of Directors in the year preceding the calculation of dependent variables in the model, squared;

$(\text { INDEP })^{2}=$ Number of independent people in the Board of Directors in the year preceding the calculation of dependent variables in the model, squared;

SEGR $=$ Binary variable representing the segregation between the president of the Board of Directors (Chairman) and the chief executive officer (CEO), where 1 represents segregation and 0 the opposite, in the year preceding the calculation of dependent variables in the model;

$\mathrm{GC}=$ Binary variable indicating whether the company is listed on one of the specific segments of corporate governance on the BM\&FBOVESPA (Level 1, Level 2, and New Market), where 1 represents presence in a specific segment and 0 for the opposite;

AT $=$ Natural logarithm of the company total assets, representing company size;

Alav $=$ The company leverage level.

\section{ANALYSIS OF RESULTS}

Below, the results obtained are interpreted according to each hypothesis defined in the research.

$\left(\mathrm{H}_{1}\right)$ The companies listed at the various corporate governance levels on the BM\&FBOVESPA (Level 1, Level 2, and New Market) are those having better fiscal mana- gement, as a consequence, they are those with lower ETR and CashETR indexes, as well as positive BTD figures.

Table 1 shows the ETR of companies in the sample between the years 2001 and 2014, separated into four segments on the BM\&FBOVESPA.

Table 1

Effective Tax Rate by segment of the Stock Exchange

\begin{tabular}{|c|c|c|c|c|c|}
\hline ETR & Level 1 & Level 2 & New Market & Traditional & All Segments \\
\hline Companies & 34 & 19 & 105 & 197 & 355 \\
\hline 2001 & $13 \%$ & $180 \%$ & $21 \%$ & $26 \%$ & $20 \%$ \\
\hline 2002 & $38 \%$ & $23 \%$ & $60 \%$ & $27 \%$ & $38 \%$ \\
\hline 2003 & $26 \%$ & $51 \%$ & $36 \%$ & $28 \%$ & $29 \%$ \\
\hline 2004 & $28 \%$ & $28 \%$ & $26 \%$ & $30 \%$ & $28 \%$ \\
\hline 2005 & $26 \%$ & $40 \%$ & $29 \%$ & $28 \%$ & $27 \%$ \\
\hline 2006 & $20 \%$ & $35 \%$ & $14 \%$ & $29 \%$ & $24 \%$ \\
\hline 2007 & $27 \%$ & $33 \%$ & $23 \%$ & $30 \%$ & $28 \%$ \\
\hline 2008 & $-23 \%$ & $84 \%$ & $23 \%$ & $29 \%$ & $12 \%$ \\
\hline 2009 & $31 \%$ & $25 \%$ & $25 \%$ & $26 \%$ & $28 \%$ \\
\hline 2010 & $24 \%$ & $34 \%$ & $27 \%$ & $24 \%$ & $25 \%$ \\
\hline 2011 & $12 \%$ & $34 \%$ & $31 \%$ & $23 \%$ & $21 \%$ \\
\hline 2012 & $23 \%$ & $32 \%$ & $29 \%$ & $29 \%$ & $27 \%$ \\
\hline 2013 & $39 \%$ & $35 \%$ & $23 \%$ & $23 \%$ & $27 \%$ \\
\hline 2014 & $29 \%$ & $28 \%$ & $26 \%$ & $27 \%$ & $27 \%$ \\
\hline Total & $22 \%$ & $34 \%$ & $26 \%$ & $27 \%$ & $25 \%$ \\
\hline
\end{tabular}




\begin{tabular}{|c|c|c|c|c|c|}
\hline 2001-2014 Percentage Points & 16 & -152 & 5 & 1 & 7 \\
\hline $\begin{array}{c}\text { 2001-2014 Percentage } \\
\text { Variation }\end{array}$ & $123 \%$ & $-84 \%$ & $24 \%$ & $4 \%$ & $35 \%$ \\
\hline
\end{tabular}

Source: Prepared by the authors.

It may be inferred from Table 1 that the average ETR of companies in the sample between the years 2001 and 2014 was $25 \%$. The segment that had the lowest effective tax rate was Level 1, with an average ETR of $22 \%$, followed by the New Market, with an average ETR of $26 \%$. The segment with the highest average ETR was Level 2, with $34 \%$, accompanied by the segment Traditional, with $27 \%$.

Also, it is noteworthy that the average ETR for the year 2008 was $12 \%$, mainly because of the negative ETR at Level $1(-23 \%)$, something which contributed to reduce the average ETR in this segment (21\%). This considerable decrease was due to the merger between ITAÚ and UNIBANCO, which generated tax benefits amounting to R $\$ 12$ million, as highlighted in the notes by ITAÚSA - Investimentos ITAÚ S.A. (Note 15) and ITAÚ UNIBANCO Holding S.A. (Note 14). According to Roberto Egydio Setúbal (2008), president of ITAÚ, the merger between ITAÚ and UNIBANCO has generated significant premium that could be amortized on the calculation basis of IRPJ and CSLL.

Table 1 also shows that three out of the four segments under analysis showed an increased ETR, and Level 1 increased by 16 percentage points, representing a $123 \%$ positive variation. On the other hand, Level 2 had a significant negative variation, with $84 \%$, which means a decrease of 152 percentage points. The segment New Market had a $24 \%$ positive variation, with an increase of five percentage points. In turn, the segment Traditional had a positive variation of $4 \%$, with an increase of one percentage point in the ETR. Such changes have led to a $35 \%$ positive variation in the companies' total ETR within the period under analysis, making it increase by seven percentage points.

The result obtained in our research is contrary to that found by Yin (2003). In the study carried out by this author, the ETR calculated for a sample of U.S. companies decreased almost constantly between 1995 and 2000 , going from $28.85 \%$ in 1995 to $24.20 \%$ in 2000 , representing a $16 \%$ decline.

The result shown herein is also opposite to that shown in the study by McIntyre and Nguyen (2000), who analyzed 250 large U.S. companies between 1996 and 1998. The authors identified a decreased number of companies whose effective tax rates were above 30\%, as they were 78 in 1996 and became 52 in 1998. In addition, the study showed an increased number of companies with effective rates below $30 \%$ within the same period, going from 97 to 104 . The survey also showed a reduced effective tax rate in the companies under analysis, dropping from $22.9 \%$ in 1996 to $20.1 \%$ in 1998.

The ETR is criticized due to some drawbacks, such as: (i) it is calculated annually and, on that basis, its variations may lead the reader to make mistakes and they are also not consistent with tax management; (ii) its calculation takes into account deferred taxes, which may mask tax management, as companies can decrease the current tax, but increase it in the future, and this fact will be masked by adding deferred taxes; and (iii) variation in the ETR may occur due to factors unrelated to tax management.

To overcome these drawbacks, Dyreng et al. (2008) proposed the Cash Effective Tax Rates - CashETR as another way to identify tax management, where expenses on taxes on earnings are added in the long term and this value is divided by the sum of earnings within the same period. This measure prevents variation in the effective tax rate due to values unrelated to tax management.

Table 2 shows the CashETR of companies in the sample between 2001 and 2014, and the values displayed refer to the sum from 2001 to 2014, i.e. the year 2001 is related only to taxes and earnings for 2001, 2002 is related to taxes and earnings for 2001 and 2002, and so on, until 2014.

Table 2

CashETR by segment

\begin{tabular}{|c|c|c|c|c|c|}
\hline CashETR & Level 1 & Level 2 & New Market & Traditional & All Segments \\
\hline Companies & 34 & 19 & 105 & 197 & 355 \\
\hline 2001 & $16 \%$ & $103 \%$ & $35 \%$ & $24 \%$ & $22 \%$ \\
\hline 2002 & $42 \%$ & $-2 \%$ & $75 \%$ & $40 \%$ & $53 \%$ \\
\hline 2003 & $28 \%$ & $34 \%$ & $37 \%$ & $30 \%$ & $30 \%$ \\
\hline 2004 & $27 \%$ & $32 \%$ & $27 \%$ & $26 \%$ & $27 \%$ \\
\hline 2005 & $25 \%$ & $43 \%$ & $30 \%$ & $29 \%$ & $28 \%$ \\
\hline
\end{tabular}




\begin{tabular}{|c|c|c|c|c|c|}
\hline & & Table 2 & Continued & & \\
\hline 2006 & $21 \%$ & $30 \%$ & $14 \%$ & $29 \%$ & $24 \%$ \\
\hline 2007 & $27 \%$ & $35 \%$ & $28 \%$ & $30 \%$ & $28 \%$ \\
\hline 2008 & $-18 \%$ & $234 \%$ & $43 \%$ & $24 \%$ & $13 \%$ \\
\hline 2009 & $31 \%$ & $13 \%$ & $41 \%$ & $27 \%$ & $31 \%$ \\
\hline 2010 & $23 \%$ & $24 \%$ & $26 \%$ & $18 \%$ & $21 \%$ \\
\hline 2011 & $14 \%$ & $27 \%$ & $24 \%$ & $16 \%$ & $17 \%$ \\
\hline 2012 & $26 \%$ & $22 \%$ & $21 \%$ & $19 \%$ & $22 \%$ \\
\hline 2013 & $44 \%$ & $22 \%$ & $18 \%$ & $18 \%$ & $25 \%$ \\
\hline 2014 & $26 \%$ & $20 \%$ & $21 \%$ & $50 \%$ & $27 \%$ \\
\hline Total & $23 \%$ & $28 \%$ & $25 \%$ & $24 \%$ & $24 \%$ \\
\hline 2001-2014 Percentage Points & 10 & -83 & -14 & 26 & 5 \\
\hline $\begin{array}{c}\text { 2001-2014 Percentage } \\
\text { Variation }\end{array}$ & $63 \%$ & $-81 \%$ & $-40 \%$ & $108 \%$ & $23 \%$ \\
\hline
\end{tabular}

Source: Prepared by the authors.

It may be inferred from Table 2 that the segments having the largest negative variations refer to companies in the sample listed on Level 2 and New Market, with 81\% and $40 \%$ decreases, respectively. On the other hand, the segment Traditional increased by $108 \%$, followed by Level 1, with 63\%. However, the average CashETR in Brazilian companies is $24 \%$. In this estimate, New Market and Traditional were $25 \%$ and $24 \%$, respectively.

Comparing this research with that by Dyreng et al. (2008), it is noticed that the CashETR (24\%) in Brazilian companies listed on the sample is lower than that showed by the authors, which was $29.6 \%$, i.e. 5.6 percentage points less than the CashETR in U.S. companies included in that sample.
According to Shevlin (2002), Desai and Dharmapala (2006), Plesko (2004), McGill and Outslay (2004), Tang (2005), and Tang and Firth (2010), the BTD estimate is an effective way to identify tax management in companies, because if book earnings are higher than taxable earnings, there is evidence of tax management to reduce the calculation basis of taxes on earnings.

Therefore, if the difference between book earnings and taxable earnings is positive, there is an indication of the presence of tax management, because it demonstrates that book earnings are higher than the calculation basis of taxes on earnings.

Table 3 shows the BTD of companies in the sample between the years 2001 and 2010.

Table 3 BTD by segment (R\$ million)

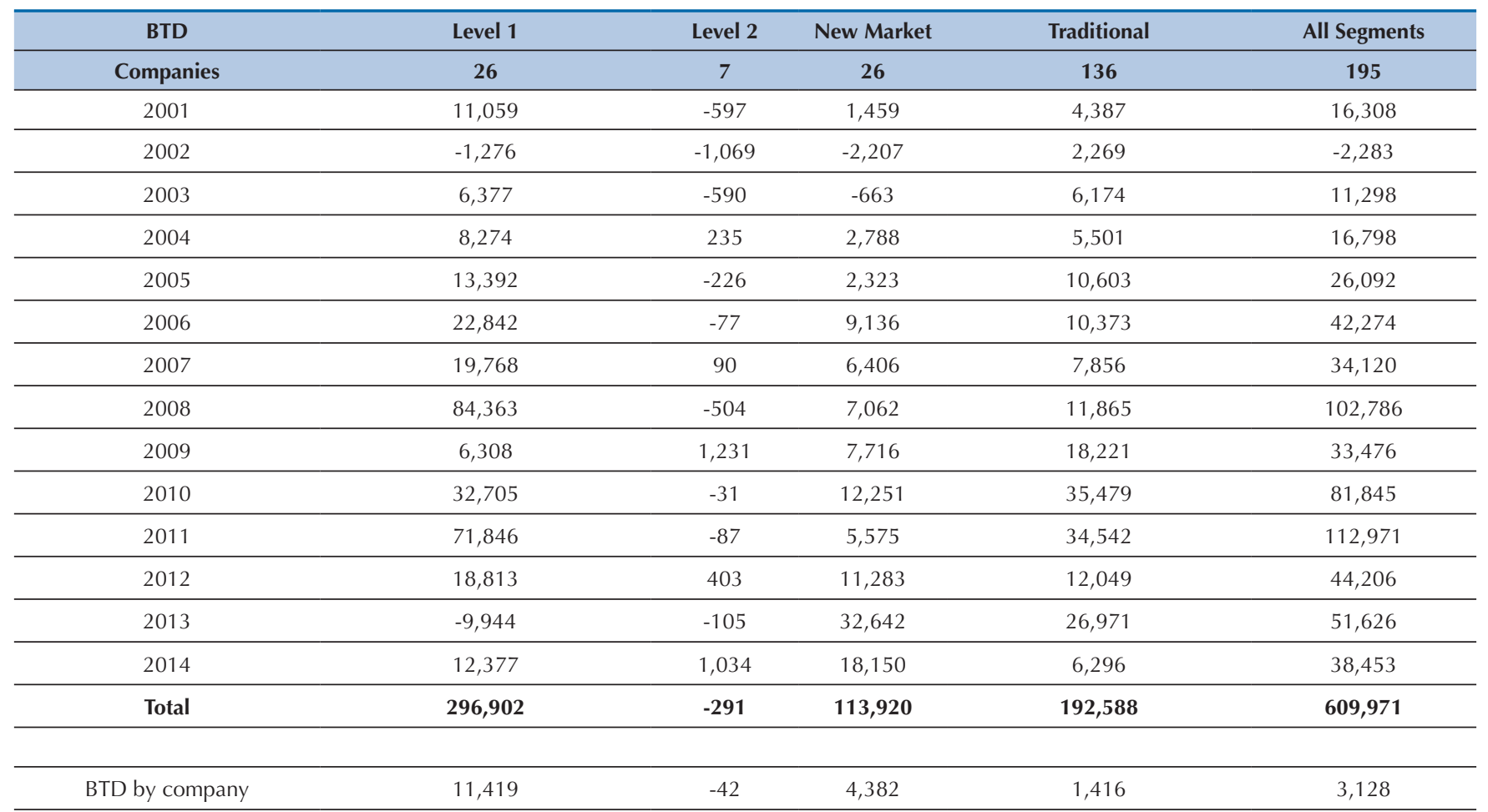


Table 3

Continued

\begin{tabular}{ccccc}
\hline 2001-2014 Difference & 1,318 & 1,631 & 16,691 & 22,145 \\
\hline $\begin{array}{c}\text { 2001-2014 Percentage } \\
\text { Variation }\end{array}$ & $12 \%$ & $-273 \%$ & $1,144 \%$ & $43 \%$ \\
\hline $\begin{array}{l}\text { 2001-2014 Percentage } \\
\text { Variation by company }\end{array}$ & $3 \%$ & $-93 \%$ & $200 \%$ & $-68 \%$ \\
\hline
\end{tabular}

Source: Prepared by the author.

According to Table 3, the total difference between book earnings and taxable earnings, between 2001 and 2014, was R\$ 610 billion, and Level 1 was the most representative, with R\$ 297 billion, followed by Traditional market, with R\$ 192 billion, and New Market, with R\$ 114 billion. Level 2 showed a negative difference, i.e. taxable earnings were greater than book earnings in 2001, and in 2014 this was reversed, book earnings became greater than taxable earnings.

Table 3 also shows a positive BTD evolution, i.e. a positive evolution of the difference between book earnings and taxable earnings, in all segments under analysis, something which means that all companies started having greater book earnings than taxable earnings. This fact may have been motivated by the separation between book earnings and taxable earnings since 2008, when the Brazilian Transition Tax Regime (RTT) was established, which deals with tax adjustments derived from the new accounting methods and criteria introduced by Law $11,638 / 2007$, and by the articles 36 and 37 of the Brazilian Provisional Act 449/2008, turned into articles 37 and 38 of Law 11,941/2009 and now repealed by Law 12,973/2014.

So, it is clear that within these 14 years the Brazilian companies in the sample did not ignore tax management, as in all segments there was a decrease in taxable earnings when compared to book earnings, something which demonstrates that the Brazilian companies under analysis have been constantly working to reduce taxable earnings in relation to book earnings.

However, the results reported herein reject $\left(\mathrm{H}_{1}\right)$, i.e. companies listed on specific levels are more efficient in tax management, since the tests demonstrated, in short, that companies at specific corporate governance levels have a worse fiscal management for the ETR Index, the same management as for the CashETR Index, and better management for the BTD Index.

Using the non-parametric Mann-Whitney test, since the data under analysis do not have a normal distribution, as evidenced by applying the Anderson-Darling normality test, the results shown in Table 4 were obtained.

Table $4 \quad$ Non-parametric Mann-Whitney test

\begin{tabular}{|c|c|c|c|c|c|c|c|}
\hline \multirow[b]{2}{*}{ Management Index } & \multirow[b]{2}{*}{ Market } & \multirow[b]{2}{*}{ Specific Median } & \multirow[b]{2}{*}{ Traditional Median } & \multirow{2}{*}{$\begin{array}{l}\text { Estimated } \\
\text { Difference }\end{array}$} & \multicolumn{2}{|c|}{$95 \% \mathrm{CI}$} & \multirow[b]{2}{*}{ Significance } \\
\hline & & & & & $\begin{array}{c}\text { Lower } \\
\text { Threshold }\end{array}$ & $\begin{array}{c}\text { Higher } \\
\text { Threshold }\end{array}$ & \\
\hline ETR & Level 1 & 0.2395 & 0.2611 & -0.0121 & -0.0365 & 0.0132 & 0.1725 \\
\hline ETR & Level 2 & 0.3246 & 0.2611 & 0.07 & 0.0411 & 0.1022 & 0.0000 \\
\hline ETR & New Market & 0.2787 & 0.2611 & 0.0289 & 0.0109 & 0.0472 & 0.0007 \\
\hline CASH_ETR & Level 1 & 0.2474 & 0.26335 & -0.0007 & -0.02369 & 0.477 & 0.477 \\
\hline CASH_ETR & Level 2 & 0.2998 & 0.26355 & 0.032 & 0.00459 & 0.0601 & 0.0114 \\
\hline CASH_ETR & New Market & 0.232 & 0.26355 & -0.025 & -0.04211 & -0.0078 & 0.0023 \\
\hline BTD & Level 1 & 75,460 & 8,930 & 57,972 & 40,587 & 77,714 & 0.0000 \\
\hline BTD & Level 2 & 3,123 & 8,930 & $-15,438$ & $-32,689$ & $-2,684$ & 0.0067 \\
\hline BTD & New Market & 31,603 & 8,930 & 13,656 & 5,263 & 22,691 & 0.0008 \\
\hline
\end{tabular}

Source: Prepared by the author.

Regarding the ETR Index, we may conclude that companies listed at Level 1 have as their median value the same index that Traditional companies. In turn, those listed at Level 2 and New Market have higher median values for the index, when compared to Traditional companies.

For the CashETR Index, we notice that companies at Level 1 have the same median values than Traditional companies. When compared to the latter, companies at Level 2 have higher median values, and those at New Market have lower median values.

Regarding the BTD Index, only companies listed at Level 2 have lower median values than Traditional companies.

In short, companies at specific corporate governance levels have a worse fiscal management for the ETR Index, the same management as for the CashETR Index, and better management for the BTD Index. 


\begin{tabular}{lcc}
\hline ETR & CashETR & BTD \\
\hline Level $1=$ Traditional & Level $1=$ Traditional & Level $1>$ Traditional \\
\hline Level $2>$ Traditional & Level $2>$ Traditional & Level $2<$ Traditional \\
\hline New Market $>$ Traditional & New Market $<$ Traditional & New Market $>$ Traditional \\
\hline Specific Level $>$ Traditional & Specific Level $=$ Traditional & Specific Level $>$ Traditional \\
\hline
\end{tabular}

Source: Prepared by the author.

Anyway, the results shown herein demonstrate that Brazilian companies do not ignore the benefits of tax management, since the effective rate in the sample between 2001 and 2014 was $25 \%$, i.e. nine percentage points below the nominal tax rate on earnings (34\%).
Besides, 1-sample signal test showed that the median values for the ETR and CashETR indexes are lower than the reference value 0.34 , something which statistically shows that Brazilian companies do not ignore the benefits of tax management.

Table 6

Signal Test

\begin{tabular}{lcc}
\hline Management Index & Market & PValue \\
\hline ETR & Level 1 & 0 \\
\hline ETR & Level 2 & 0.0143 \\
\hline ETR & New Market & 0 \\
\hline CashETR & Level 1 & 0 \\
\hline CashETR & Level 2 & 0 \\
\hline CashETR & New Market & 0 \\
\hline Source: Prepared by the author & &
\end{tabular}

The hypotheses $\left(\mathbf{H}_{1}\right.$ to $\left.\mathbf{H}_{6}\right)$ established in this research have corporate governance aspects as a premise, such as key items of tax management in Brazilian companies. Besides, $\mathbf{H}_{7}$ regards tax management within the preceding period as reflected on tax management in the sub- sequent period.

Figure 2 shows an overview of the corporate governance characteristics that were regarded as explanatory variables of the study, relating them to the expected link between proxies and tax management.

\begin{tabular}{|c|c|c|}
\hline Variable & Proxies & Expected Signal \\
\hline ETR-1; CashETR-1; BTD-1 & Dependent variable lagged one year & + \\
\hline Rem & $\begin{array}{l}\text { Variable remuneration paid to the executive board } \\
\text { in the year subsequent to the calculation of the } \\
\text { dependent variable }\end{array}$ & - \\
\hline Comp & $\begin{array}{c}\text { Number of members in the Board of Directors in } \\
\text { the year preceding the calculation of the dependent } \\
\text { variable }\end{array}$ & + \\
\hline Indep & $\begin{array}{l}\text { Number of independent members in the Board of } \\
\text { Directors in the year preceding the calculation of } \\
\text { the dependent variable }\end{array}$ & - \\
\hline Segr & $\begin{array}{c}\text { Segregation between Chairman and CEO in the } \\
\text { year preceding the calculation of the dependent } \\
\text { variable }\end{array}$ & - \\
\hline Gc & $\begin{array}{l}\text { Company listed on the specific corporate governan- } \\
\text { ce levels }\end{array}$ & - \\
\hline At & Company size (natural logarithm of total assets) & + \\
\hline Alav & Financial Leverage: total debt on Equity & - \\
\hline
\end{tabular}

Figure 2 Explanatory Variables

Source: Prepared by the author.

It is worth highlighting that, in this research, a company is regarded as efficient in tax management when it has a lower effective tax rate on earnings. Besides, it is believed that corporate governance characteristics adop- 
ted by companies influence tax management. In face of this, the negative signal expected means that variable is likely to decrease the effective tax rate of the company. On the other hand, the positive signal indicates that the higher this variable is, the higher the effective rate is, i.e., the effective rate increases according to the increase in the variable.

$\left(\mathbf{H}_{2}\right)$ The specific corporate governance levels on the BM\&FBOVESPA (Level 1, Level 2, and New Market) have a significant negative relationship with the proxies to identify tax management ETR, CashETR, and BTD.

$\left(\mathbf{H}_{3}\right)$ The number of members in the Board of Directors in the preceding year contributes to tax management in firms, so the number of counselors has a significant relationship with the proxies to identify tax management ETR, CashETR, and BTD.

$\left(\mathbf{H}_{4}\right)$ Independent Boards of Directors are more efficient concerning fiscal management, as they recommend the executive board to invest resources in such activities, so the number of independent counselors in the preceding year has a significant negative relationship with the proxies to identify tax management ETR, CashETR, and BTD.

$\left(\mathbf{H}_{5}\right)$ Companies with segregation between Chairman and $\mathrm{CEO}$ are more efficient concerning fiscal management, so this dummy has a significant negative relationship with the proxies to identify tax management ETR, CashETR, and BTD.

$\left(\mathbf{H}_{6}\right)$ Companies that adopt executive board variable remuneration are more efficient concerning fiscal management, so executive board remuneration has a significant negative relationship with the proxies to identify tax management ETR, CashETR, and BTD.

$\left(\mathbf{H}_{7}\right)$ Tax management within the preceding period is reflected on tax management in the subsequent period, so the dependent variables to identify tax management ETR, CashETR, and BTD lagged one year have a significant relationship with the proxies to identify tax management.

To use this methodology, first there must be established which is the most suitable panel for data analysis. Figure 3 shows the test results.

\begin{tabular}{|c|c|c|c|c|}
\hline \multirow{2}{*}{ Tests } & \multirow{2}{*}{ Hypotheses } & \multicolumn{3}{|c|}{ Models } \\
\hline & & ETR (1) & CashETR (2) & BTD (3) \\
\hline \multirow[b]{2}{*}{ Chow } & $\begin{array}{l}\mathrm{H}_{0}: \text { The intercept is the same for all } \\
\text { companies (pooling). }\end{array}$ & \multirow[b]{2}{*}{ Prob $>F=0.0000$} & \multirow[b]{2}{*}{ Prob $>F=0.0000$} & \multirow[b]{2}{*}{ Prob $>F=0.0000$} \\
\hline & $\begin{array}{c}\mathrm{H}_{1}: \text { The intercept is different for all } \\
\text { companies (fixed effects). }\end{array}$ & & & \\
\hline \multirow[b]{2}{*}{ Breusch Pagan } & $\begin{array}{c}\mathrm{H}_{0}: \text { The variance of residues reflec- } \\
\text { ting individual differences is equal } \\
\text { to zero (pooling). }\end{array}$ & \multirow[b]{2}{*}{ Prob $>F=0.0000$} & \multirow[b]{2}{*}{ Prob $>F=0.0000$} & \multirow[b]{2}{*}{ Prob $>F=0.0016$} \\
\hline & $\begin{array}{l}\mathrm{H}_{1} \text { : The variance of residues } \\
\text { reflecting individual differences is } \\
\text { different from zero (random effects). }\end{array}$ & & & \\
\hline \multirow[b]{2}{*}{ Hausman } & $\begin{array}{l}\mathrm{H}_{0} \text { : The error correction model } \\
\text { (random effects) is suitable. }\end{array}$ & \multirow[b]{2}{*}{0.0449} & \multirow[b]{2}{*}{0.0043} & \multirow[b]{2}{*}{0.2217} \\
\hline & $\begin{array}{c}\mathrm{H}_{1}: \text { The fixed effects model is } \\
\text { suitable. }\end{array}$ & & & \\
\hline \multicolumn{2}{|c|}{ Most appropriate Panel Model } & Fixed Effects & Fixed Effects & Random Effects \\
\hline
\end{tabular}

Figure $3 \quad$ Test results - identification of the panel model Source: Prepared by the author.

Based on Figure 3, it is clear that the model for panel data with random effects was the most suitable for data analysis in the BTD. However, for the ETR and CashETR the most suitable for data analysis is the fixed effects panel. Furthermore, models' validation revealed, by using Wooldridge self-correction tests and heteroscedasticity likelihood ratio, that the models have problems concerning self-correlation and heteroscedasticity. Thus, the models proposed by GLS were estimated by making adjustments for AR1 and heteroscedasticity.

Below, the results of regressions are shown with panel data for the three models of this study.

\subsection{Panel Data Model for the Variable ETR}

In the model displayed in Table 7, we notice that tax management within the preceding period is reflected on tax management in the subsequent period, since the variable ETR-1 is statistically significant. Moreover, just as in the papers by Minnick and Noga (2010) and Armstrong et al. (2011), variable remuneration has proven to be significant before the ETR index. The variables corporate governance control and leverage were also significant, as well as the constant value in the equation. 
Table 7 Panel Data Model for the ETR - GLS

\begin{tabular}{|c|c|c|c|c|}
\hline Variable & Coefficient & Standard Error & T-Statistics & $P>|t|$ \\
\hline ETR-1 & 0.2185358 & 0.0455637 & 4.80 & $0.000^{*}$ \\
\hline Rem & -0.0013671 & 0.0009277 & -1.47 & $0.001^{*}$ \\
\hline Comp & 0.0000155 & 0.0000283 & 0.55 & 0.584 \\
\hline Indep & 0.000433 & 0.0005494 & 0.79 & 0.431 \\
\hline Segr & 0.0083521 & 0.0195102 & 0.43 & 0.669 \\
\hline Gc & 0.0642535 & 0.0191871 & 3.35 & $0.001^{*}$ \\
\hline At & -0.0008508 & 0.0032195 & -0.26 & 0.792 \\
\hline Alav & -0.000022 & 6.2406 & -3.53 & $0.000^{*}$ \\
\hline Constante & 0.1590044 & 0.0506975 & 3.14 & $0.002 *$ \\
\hline
\end{tabular}

* Statistically significant at $1 \%$.

Source: Prepared by the author.

\subsection{Panel Data Model for the Variable CashETR}

Just as in the model in Table 7, the model in Table 8 demonstrates that tax management within the preceding period is reflected on tax management in the subsequent period. Besides, the results shown herein are consistent with the papers by Minnick and Noga (2010), Dyreng et al. (2010), and Rego and Wilson (2010), who identified a significant relationship between remuneration and $\mathrm{Ca}$ shETR. In this model, no significant relationship was noticed between corporate governance and the dependent variable. Finally, the leverage control variable was significant, as well as the model constant value.

Table 8 Panel data model - CashETR - GLS

\begin{tabular}{|c|c|c|c|c|}
\hline Variable & Coefficient & Standard Error & T-Statistics & $P>|t|$ \\
\hline CASH-1 & 1.2806 & 4.0607 & 3.16 & $0.002 *$ \\
\hline Rem & -0.001713 & 0.0006703 & -2.56 & $0.011^{*}$ \\
\hline Comp & -1.8006 & 0.0000511 & -0.04 & 0.972 \\
\hline Indep & 1.3006 & 0.0011589 & 0.00 & 0.999 \\
\hline Segr & 0.024454 & 0.0247552 & 0.99 & 0.323 \\
\hline Gc & -0.012018 & 0.0258226 & -0.47 & 0.642 \\
\hline At & 0.001273 & 0.0023539 & 0.54 & 0.589 \\
\hline Alav & 0.000017 & 4.4006 & 3.97 & $0.000^{*}$ \\
\hline Constante & 0.209582 & 0.0408765 & 5.13 & $0.000^{*}$ \\
\hline
\end{tabular}

* Statistically significant at $1 \%$.

Source: Prepared by the author.

\subsection{Panel Data Model for the Variable BTD}

The model in Table 9, just as in previous models shown in tables 7 and 8 , the fiscal management wi- thin the preceding period was statistically significant, reflecting on tax management in the subsequent period.

\section{Table 9}

\begin{tabular}{|c|c|c|c|c|}
\hline Variable & Coefficient & Standard Error & T-Statistics & $P>|t|$ \\
\hline BTD-1 & 0.4062453 & 0.0213536 & 19.02 & $0.000^{*}$ \\
\hline Rem & -0.012217 & 0.0044779 & -2.73 & 0.006* \\
\hline Comp & $-368,189$ & $1,488,941$ & -2.47 & 0.013* \\
\hline Indep & $2,562,706$ & $2,392,256$ & 1.07 & 0.284 \\
\hline Segr & $106,788.4$ & $59,079.05$ & 1.81 & $0.071^{* *}$ \\
\hline Gc & $-15,923.87$ & $59,156.1$ & -0.27 & 0.788 \\
\hline At & $44,712.81$ & $12,653.12$ & 3.53 & $0.000^{*}$ \\
\hline Alav & $-1,605,157$ & $2,589,215$ & -0.62 & 0.535 \\
\hline Constante & $-577,942$ & $185,451.9$ & -3.12 & $0.002^{*}$ \\
\hline
\end{tabular}

* Statistically significant at $1 \%$.

** Statistically significant at 7\%

Source: Prepared by the author. 
The coefficient of variable remuneration (Rem) was statistically significant at $1 \%$, just as in the other models. Therefore, it may be concluded that remuneration negatively influences the tax management detected by means of the variable BTD. This finding is consistent with the papers by Desai and Dharmapala (2006), Minnick and Noga (2010), Dyreng et al. (2010), Rego and Wilson (2010), and Armstrong et al. (2011), who identified a significant relationship between remuneration and BTD.

Finally, $\mathbf{H}_{6}$ and $\mathbf{H}_{7}$ may be proven by the results, demonstrating that remuneration and the previous tax management influence the tax management detected through ETR, CashETR, and BTD, regardless of the fact that the company is classified at specific levels on the BM\&FBOVESPA or at the traditional Market, as the control variable (Gc) was significant only in the model in Table 6.

\section{FINAL REMARKS}

The main aim of this study was checking whether corporate governance characteristics, such as executive board remuneration, segregation between Chairman and CEO, and independence and composition of the Board of Directors influence tax management in Brazilian companies, as well as demonstrating whether previous tax management affects future tax management.

To meet the general objective of this study, first tax management was identified in Brazilian companies by calculating three proxies - ETR, CashETR, and BTD. Two main findings were identified, namely: (i) previous tax management influences tax management in the subsequent period; and (ii) remuneration may be regarded as a characteristic that influences tax management, just as in the papers by Desai and Dharmapala (2006), Minnick and Noga (2010), Dyreng et al. (2010), Rego and Wilson (2010), and Armstrong et al. (2011).

Also, the variable composition of the Board of Directors was significant only in the model analyzing the BTD. The control variable corporate governance was reflected only on the equation to analyze the ETR, and the control variable total assets was significant only in the equation to the BTD. The control variables leverage and constant value were significant in the models for CashETR and BTD, and for the ETR only constant value was significant.

Thus, this research shows that executive board variable remuneration is related to tax management. In this way, it may be concluded that a proper design of variable remuneration contracts may lead to an effective tax management, with a consequent increase in company performance. Through variable remuneration and tax management, we may align managers' interests to shareholders' inte- rests. Besides, tax management is reflected on fiscal management in the subsequent periods.

However, both this research and the other studies cited on tax management are not conclusive as for the actual executives' engagement in tax management, and they also do not make clear whether the documented tax effects are a by-product of investment, funding, or operational decisions within the company.

Another result shows that Brazilian companies do not disregard the benefits of tax management, given that the median values of tax management proxies (ETR, CashE$\mathrm{TR}$, and BTD) are statistically different from the nominal tax rate in Brazil, which was $34 \%$. In the tests applied, it was demonstrated that the median value is statistically lower than the nominal rate.

A limitation of this research refers to the population under analysis, since it was an intentional and non-probabilistic sample. In this way, the results of analyses are restricted to the companies under study. Of course, generalizations to another set of companies are not directly feasible.

It is recommended, for further research, to provide in-depth analysis of the strategies adopted by Brazilian companies to reduce taxable earnings in relation to book earnings, as well as to replicate the same study in companies not listed on the stock exchange. Other aspects that deserve to be addressed refer to the relationships between tax management and companies' financial performance proxies, such as ROA, ROE, and EBITDA, as well as an assessment of the way how the stock market reacts to this management by analyzing market proxies, such as $\mathrm{P} / \mathrm{L}$, $\mathrm{P} / \mathrm{B}$, and $\mathrm{MVA}^{\oplus}$, among others. 
Agrawal, A., \& Knoeber, C. (1996). Firm performance and mechanisms to control agency problems between managers and shareholders. Journal of Financial and Quantitative Analysis, 31, 377-397.

Armstrong, C. S., Blouin, J. L., \& Larcker, D. F. (2011). The Incentives for Tax Planning Journal of Accounting and Economics, 53(1), $391-411$

Bankman, J. (1999). The new market in corporate tax shelters. Tax Notes, $83,1775-1794$.

Barnhart, S., \& Rosenstein, S. (1998). Board composition, managerial ownership and firm performance: an empirical analysis. The Finaricial Review 33, 1-16.

Baysinger, B., \& Butler, H: (1985). Corporate governance and the board of directors: performance effects of changes in board composition. Journal of Law, Economics and Organization, 1, $101-124$

Bhagat, S., \& Black, B. (2000). The uncertain relationship between board composition and firm performance. Business Lawyer, 54, 921-963.

Borokovich, K., Parrino, R., \& Trapani, T. (1996). Outside directors and CEO selection. Journal of Financial and Quantitative Analysis, $31,337-355$

Boyd, B. K. (1994). Board control and CEO compensation. Strategic Management Journal, 15(5), 335-344.

Brown, W. O., \& Maloney, M. T. (1999). Exit, voice, and the role of corporate directors: evidence from acquisition performance. Working paper. Retrieved on March 10, 2012, from http://dx.doi. org/10.2139/ssrn.160308

Byrd, J.; \& Hickman, K. (1992). Do outside directors monitọ managers? Evidence from tender offer bids. Journal of Financial Economics, 32, 195-222.

Callihan, D. (1994). Corporate effective tax rates: a synthesis of the literature. Journal of Accounting Literature, 13, 1-43.

Cardoso, R. L., Mário, P. de C., \& Aquino, A. C. B. de (2007). Contabilidade gerencial: mensuração, monitoramento e incentivos. São Paulo: Atlas.

Coles, J. L., Daniel, N. D., \& Naveen, L. (2008). Boards: Does One Size Fit All? Journal of Financial Economics, 87(2), 329-356.

Comissão de Valores Mobiliários (2002). Recomendações da CVM sobre governança corporativa. Retrieved on December 11, 2008 from http://www.cvm.org.br

Comprix, J., Mills, L. F., \& Schmidt, A. P. (2011). Bias in Quarterly Estimates of Annuål Effective Tax Rates and Earnings Management. The Journal of the American Taxation Association, $34(1), 31-53$.

Core, J., Holthausen, R., \& Larcker, D. (1999). Corporate governance, chief executive officer compensation, and firm performance. Journal of Financial Economics, 51, 371-406.

Coughlan, A., \& Schmidt, R. (1985). Executive compensation, management turnover, and firm performance. Journal of Accounting and Economics, 7, 43-66.

Desai, M. A., \& Dharmapala, D. (2006). Corporate tax avoidance and high-powered incentives. Journal of Financial Economics, 79(1), $145-179$

Desai, M. A:, \& Dharmapala, D. (2007). Taxation and Corporate Governance: An Economic Approach. Retrieved on July 26, 2011, from http://dx.doi.org/10.2139/ssrn.983563

Dyreng, S., Hanlon, M., \& Maydew, E. (2008). Long-run corporate tax avoidance. The Accounting Review, 83, 61-82.

Dyreng, S., Hanlon, M., \& Maydew, E. (2010). The Effects of Executives on Corporate Tax Avoidance. Retrieved on January 16, 2012, from http://ssrn.com/abstract $=1158060$

Eisenberg, T., Sundgren, S., \& Wells, M. (1998). Larger board size and decreasing firm value in small firms. Journal of Financial Economics, 48, 35-54

Fama, E. (1980). Agency problems and the theory of the firm. Journal of Political Economy, 88(2), 288-307.

Fama, E., \& Jensen, M. (1983). Separation of ownership and control. Journal of Law and Economics, 26, 301-327.

Formigoni, H., Antunes, M. T. P., \& Paulo, E. (2009). Diferença entre Lucro Contábil e Lucro Tributável: Uma Análise sobre o Gerenciamento de Resultados Contábeis e Gerenciamento Tributário nas Companhias Abertas Brasileiras. Brazilian Business Review, 6(1), 44-61.

Frank, M. M., Lynch, L. \& Rego, S. (2009). Tax reporting aggressiveness and its relation to aggressive financial reporting.
The Accounting Review, 84(2), 467-496.

Füerst, O., \& Kang, S. (2000). Corporate governance, expected operating performance, and pricing. Work in Progress, v.2.2, Yale School of Management, New Haven, CT: Retrieved on July 22, 2011, from http://ssrn.com/abstract=141357

Goncharov, I., \& Zimmermann, J. (2005). Earnings Management when Incentives Compete: The Role of Tax Accounting in Russia. Retrieved on December 29, 2010, from http://ssrn.com/ abstract $=622640$

Graham, J. R. (2003). Taxes and Corporate Finance: A Review. Review of Financial Studies (Forthcoming). Recuperado em 26 julho, 2011, de http://ssrn.com/abstract $=358580$

Graham, J., \& Tucker, A. (2006). Tax shelters and corporate debt policy. Journal of Financial Economics, 81(3), 563-594.

Gupta, S., \& Mills, L. F. (2002). Corporate Multistate Tax Planning: Benefits of Multiple Jurisdictions. Journal of Accounting and Economics 33(1), 117-139.

Gupta, S., \& Newberry, K. (1997). Determinants of the variability in corporate effective tax rates: Evidence from logitudinal data. Journal of Accounting and Public Policy, 16, 1-34.

Hallock, K. F. (1997). Reciprocally interlocking boards of directors and executive compensation. Journal of Financial and Quantitative Analysis, 32(3), 331-344.

Hanlon, M. (2005). The Persistence and Pricing of Earnings, Accruals and Cash Flows When Firms Have Large Book-Tax Differences. The Accounting Review, 80(1), 137-166.

Hanlon, M., \& Slemrod, J. (2007). What does tax aggressiveness signal? Evidence from stock price reactions to news about tax aggressiveness. Working paper, University of Michigan. Retrieved on August 14; 2011, from http://ssrn.com/abstract $=975252$

Hermalin, B., \& Weisbach, M. (1991). The effects of board composition and direct incentives on firm performance. Financial Mariagement, 20, 101-112.

Instituto Brasileiro de Governança Corporativa (2011). Código das melhores práticas de governança corporativa. Retrieved on May 11, 2011, from http://www.ibgc.org.br.

Jensen, M. C. (1993). The modern industrial revolution, exit, and the failure of internal control systems. Journal of Finance, 48(3), 831-880.

Jensen, M. C. (2001). Value Maximisation, Stakeholder Theory and the Corporate Objective Function. European Financial Management, 7(3), 297-317

Jensen, M. C. \& Meckling, W. (1976). Theory of the firm: managerial behavior, agency costs and ownership structure. Journal of Financial Economics, 3(4), 305-360.

Jensen, M. C., \& Meckling, W. H. (2008). Teoria da Firma: Comportamento dos Administradores, Custos de Agência e Estrutura de Propriedade. RAE - Revista de Administração de Empresas, 48(2).

Jensen, M. C., \& Murphy, K. (1990). Performance pay and top management incentives. Journal of Political Economy, 98, 225-264.

Johnson, J., Daily, C., \& e Ellstrand, A. (1996). Boards of directors: a review and research agenda. Journal of Management, 22, 409-438.

La Porta, R., \& Vishny, R. (2000) Agency problems and dividend policies around the world. Journal of Finance, 55(1), 1-33.

Lambert, R. A., Larcker, D. F., \& Verrecchia, R. E. (1991). Portfolio consideration in the valuation of executive compensation. Journal of Accounting Research, 29(1), 129-149.

MacAvoy, P. W., Cantor, S., Dana, J., \& Peck, S. (1983). Proposals for increased control of the corporation by the board of directors: An economic analysis. In Business Roundtable (Eds.) Statement of the business roundtable on the American Law Institute's proposed principles of corporate governance and structure: Restatement and recommendations (pp. C1-C49). New York: Business Roundtable

Machado, A. P. (2011, setembro). A verdadeira alíquota dos tributos incidentes sobre os lucros das empresas brasileiras. Anais do Encontro Nacional da Associação Nacional de Pós-Graduação e Pesquisa em Administração, Rio de Janeiro, RJ, Brasil, 35.

Mattar, F. N. (1999). Pesquisa de marketing (5a ed.) São Paulo: Atlas.

McGill, G. A. \& Outslay, E. (2004). Lost in Translation: Detecting Tax Shelter Activity in Financial Statements. National Tax Journal, 57(3), 739.

McIntyre, R. S. \& Nguyen, T. D. C. (2000). Corporate income taxes in the 1990s: Washington, DC: Institute on Taxation and Economic Policy.

Mills, L., Erickson, M. M., \& Maydew, E. L. (1998). Investments in Tax 
Planning. The Journal of the American Taxation Association, 20(1) 1-20.

Mills, L. e Newberry, K. (2001). The Influence of Tax and Non-Tax Costs on Book-Tax Reporting Differences: Public and Private Firms. Journal of the American Taxation Association, 23(1), 1-19. Minnick; K., \& Noga, T. (2010). Do corporate governance characteristics influence tax management? Journal of Corporate Finance, 16(5), 703-718.

Mônaco, D. C. (2000): Estudo da Composição dos Conselhos de Administração e Instrumentos de Controle das Sociedades por Ações no Brasil. Dissertação de mestrado, Faculdade de Economia Administração e Contabilidade, Universidade de São Paulo, São Paulo, SP, Brasil.

Monks, R.A.G., \& Minow, N. (1995). Corporate governance. Cambridge, MA: Blackwell-Business.

Petroni, K. R., \& Shackelford, D. A. (1999). Managing Annual Accounting Reports to Avoid State Taxes: An Analysis of PropertyCasualty Insurers. The Accounting Review, 74(3), 371-393.

Pfeffer, J., \& Salancik, G.R. (1978). The external control of organizations: A resource dependence perspective. New York: Harper \& Row.

Phillips, J. D. (2003). Corporate Tax-Planning Effectiveness: The Role of Compensation-Based Incentives. The Accounting Review, 78(3); 847-874.

Plesko, G. A. (2004). Corporate Tax Avoidance and the Properties of Corporate Earnings. National Tax Journal, 57(3), 729-737.

Rego, S. O. (2003). Tax-Avoidance Activities of U.S. Multinational Corporations. Contemporary Accounting Research, 20(4): 805- 833

Rego, S. O., \& Wilson, R. (2010). Executive compensation, tax reporting aggressiveness, and future firm performance. Working Paper, University of Iowa. Retrieved on August 21, 2011; from https://tippie.uiowa.edu/accounting/mcgladrey/pdf/rego_wilson. pdf

Robinson, J.R., Sikes, S.A., \& Weaver, C.D. (2010). The impact of evaluating the tax function as a profit center on effective tax rates. The Accounting Review, 85(3), 1035-1064.

Rosenstein, S., \& Wyatt, J. (1990). Outside directors, board independence, and shareholder wealth. Journal of Financial Economics, 26(2), 175-191.

Salomon, D.V. (1973). Como fazer uma monografia. Belo Hörizonte: Interlivros.

Scholes, M., \& Wolfson, M. (1992). Taxes and business strategy: a planning approach. Englewood Cliffs, NJ: Prentice Hall.

Shackelford, D. A., \& Shevlin, T. J. (2000). Empirical Tax Research In Accounting. JAE Rochester Conference, April. Retrieved on January
16, 2012, from http://ssrn.com/abstract $=235796$.

Shevlin, T. J. (2002). Commentary: Corporate Tax Shelters and BookTax Differences. Tax Law Review, 55, 427-443.

Shleifer, A., \& Vishny, R. (1997). A survey of corporate governance. Journal of Finance, 52(2), 737-783.

Silveira, A. M. (2002). Governança corporativa, desempenho e valor da empresa no Brasil. Dissertação de Mestrado, Faculdade de Economia, Administração e Contabilidade, Universidade de São Paulo, São Paulo, SP, Brasil.

Silveira, A. M. (2004). Governança Corporativa e Estruturas de Propriedade: Determinantes e Relação com o Desempenho de Empresas no Brasil. Tese de Doutorado, Faculdade de Economia Administração e Contabilidade, Universidade de São Paulo, São Paulo, SP, Brasil

Silveira, A. M., Barros, L. A., Famá, R. (2003). Estrutura de governança e desempenho financeiro nas companhias abertas brasileiras - um estudo empírico. Caderno de Pesquisas em Administração da USP, 10(1), 57-71.

Stickney, C., \& McGee, V. (1982). Effective corporate tax rates: The effect of size, capital intensity, leverage, and other factors. Journal of Accounting and Public Policy, 1, 125-152.

Tang, T. Y. H. (2005). Book-Tax Differences, a Proxy for Earnings Management and Tax Management - Empirical Evidence from China. Retrieved on July 26, 2011, from http://ssrn.com/ abstract $=872389$

Tang, T., \& Firth, M. (2010). Can Book-Tax Differences Capture Earnings Management and Tax Management? Empirical Evidence from China. The International Journal of Accounting, 46(2), 175204

Wagner, J., Stimpert, L., \& Fubara, E. (1998). Board composition and organizational performance: two studies of insider/outsider effects. Journal of Management Studies, 35, 655-677.

Watts, R., \& Zimmermann, J. (1986). Positive Accounting Theory. New Jersey: Prentice-Hall

Weisbach, M. (1988). Outside directors and CEO turnover. Journal of Financial Economics, 20(1-2), 431-460.

Wilson, R. J. (2009). An examination of corporate tax shelter participants. The Accounting Review, 84(3), 969-999.

Yermack, D. (1996). Higher market valuation of companies with a small board of directors. Journal of Financial Economics, 40(2), 185-202.

Yin, G. (2003). How much do large public corporations pay? Estimating the effective tax rates of the S\&P 500. Virginia Law Review, 89, 1793-1856.

\section{Correspondence Address:}

Antônio Paulo Machado Gomes

Departamento de Ciências Contábeis, Ibmec

Rua Rio Grande do Norte, 300 - CEP: 30130-130

Funcionários - Belo Horizonte - MG

Email: antonio.gomes@ibmecmg.br 